\title{
Peertechz
}

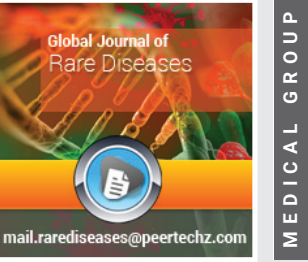

\section{Temporary improvement of motor symptoms of a patient with Parkinson's disease after accidental electric shock -}

\section{Case report}

\author{
Antônio Marcos Da Silva Catharino ${ }^{1,2 *}$, Kattiucy Gabrielle Da \\ Silva Brito', Edarlan Barbosa Dos Santos' ${ }^{1}$, Gilberto Canedo \\ Martins $^{1,2}$ and Marco Antonio Orsini Neves ${ }^{1}$ \\ ${ }^{1}$ Medicine school, Universidade Iguaçu, Unig, Rj, Brazil \\ ${ }^{2}$ Department of Neurology, Hospital Geral De Nova Iguaçu, Rj, Brazil
}

Received: 18 August, 2020

Accepted: 08 September, 2020

Published: 09 September, 2020

*Corresponding author: Antônio Marcos Da Silva Catharino, Department of Neurology, Hospital Geral De Nova Iguaçu, Rua Gavião Peixoto 70, Room 811, CEP 24.2230-100, Icaraí, Niterói-RJ, Brazil, Email: neurocurso@globo.com

Keywords: Parkinson's disease; Motor improvement; Electric shock

https://www.peertechz.com

Check for updates

\section{Abstract \\ Despite parkinson's disease to be one of the most frequent movement disorders, with motor and non-motor symptoms and pharmacological and surgical treatments, we present a case of temporary improvement of motor symptoms after an accidental electric shock and we highlight the need for furthrer studies to discuss possible mechanisms involved in this case.}

\section{Introduction}

Parkinson's Disease is one of the most frequent movement disorders, with well-established motor and non-motor symptoms. Therapeutic approach involves pharmacological and surgical treatments. We present a case of temporary improvement of motor symptoms after an accidental electric shock.

\section{Case presentation}

Male, 68 years-old, with diagnosis of parkinson disease since october 2013. he was on regular treatment with levodopa, rasagiline and rotigotine with partial improvement of symptoms. Despite de treatment he still had an asymmetric rest tremor, more severe in upper right hand, mild bilateral rigidity, bradykinesia and reduced arm swing on the rigth side. he also presented non-motor symptoms, such as hyposmia, constipation and rem sleep behavior disorder.
In september 2017, he accidentally touched his right hand to the shock end of a military tactical lantern of $28000 \mathrm{w}$ (Figure 1), while cleaning it. He received an electrical discharge, after that, presented significant improvement of tremor and rigidity. He also reported a favorable change in the performance of activities such as writing and eating tasks, as well as driving a car. The improve persists for almost twelve months after the

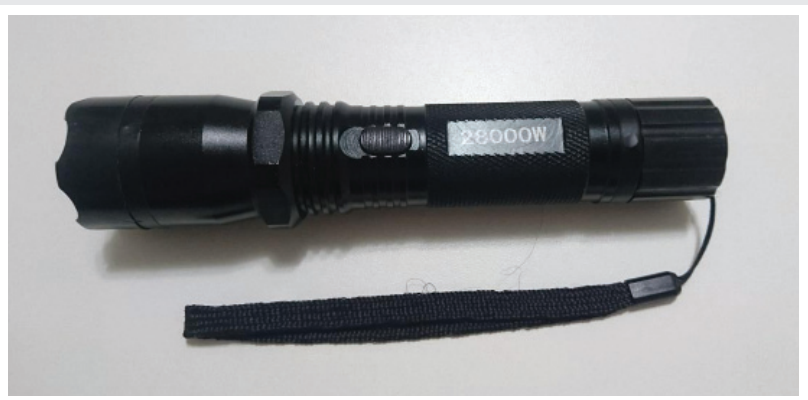

Figure 1: Military Tactical Lantern of 28000 w. 
accident, when symptoms returned. There were no changes in the other symptoms.

He was submitted to magnetic resonance of the brain and electroencephalogram, which showed no lesions that could justify the clinical improve.

\section{Discussion}

Parkinson Disease (pd) is a neurodegenerative disease that has as main motor manifestations the rest tremor, rigidity and bradykinesia, already presenting non-motor manifestations [1]. Treatment of parkinson disease is symptomatic and aims to reduce progression of disease and symptoms [1]. However, the response to treatment decreases as the disease advances.

The main therapeutic measures are the pharmacological treatment and the surgical treatment, for a selected group of patients [1]. we report a case of temporary reduction in the parkinson disease motor symptoms after an accidental electric shock.

Some authors report the use of electricity in the treatment of different diseases, such as movement disorders and migraine [2]. the use of peripheral electrical stimulation demonstrated benefit in the tremor treatment in patients with parkinson's disease on saavedra-escalona [3] study. on the other side, morris et al, report a case of parkinsonian syndrome initiated after electronic injury in the hand in a young patient [4].

\section{Conclusion}

The mechanism by which a peripheral electric injury can impact in the symptom of the parkinson disease is unknown. This interesting clinical response observed after an accidental electrical discharge highlight the need for furthrer studies on this theme.

\section{References}

1. Brasil. Ministério Da Saúde Secretaria De Atenção A Saude. Protocolo Clínico E Diretrizes Terapêuticas Da Doença De Parkinson. Brasília 2017. Link: https://bit.ly/2ZjrSER

2. Mcwhirter L, Carson A, Stone J (2015) The Body Electric: A Long View of Electrical Therapy for Functional Neurological Disorders. Brain 138: 11131120. Link: https://bit.ly/335KoBG

3. Saavedra-Escalona JL, Lupercio-Morales G, Castro-Rodriguez IE, HernándezFranco J (2005) Effect Of Tens Over Parkinson's Disease Tremor. Archivos De Neurociencias 10: 133-139. Link: https://bit.ly/2R90KUs

4. Morris HR, Moriabadi NF, Lees AJ, Dick DJ, Moriabadi NF, et al. (1998) Parkinsonism Following Electrical Injury to The Hand. Mov Disord 13: 600-602. Link: https://bit.ly/338fRmU

\section{Discover a bigger Impact and Visibility of your article publication with}

\section{Peertechz Publications}

Highlights

* Signatory publisher of ORCID

* Signatory Publisher of DORA (San Francisco Declaration on Research Assessment)

* Articles archived in worlds' renowned service providers such as Portico, CNKI, AGRIS, TDNet, Base (Bielefeld University Library), CrossRef, Scilit, J-Gate etc.

* Journals indexed in ICMJE, SHERPA/ROMEO, Google Scholar etc.

* OAI-PMH (Open Archives Initiative Protocol for Metadata Harvesting)

* Dedicated Editorial Board for every journal

* Accurate and rapid peer-review process

Increased citations of published articles through promotions

* Reduced timeline for article publication

Submit your articles and experience a new surge in publication services (https://www.peertechz.com/submission).

Peertechz journals wishes everlasting success in your every endeavours.

Copyright: @ 2020 Da Silva Catharino AM, et al. This is an open-access article distributed under the terms of the Creative Commons Attribution License, which permits unrestricted use, distribution, and reproduction in any medium, provided the original author and source are credited. 